\title{
The philosophical and evidentiary basis of homoeopathic immunisation: a response to Teixeira
}

\author{
Isaac Golden \\ Faculty of Science, Federation University, Ballarat, Australia
}

\begin{abstract}
Homoeopathic immunisation was first used in 1798, but remains controversial with some homoeopathic practitioners. Teixeira supports the use of genus epidemicus (GE) remedies, but strongly condemns the use of nosodes for disease prevention. However, Teixeira failed to fully understand the principle of similars, he used a double standard when comparing evidences using GE remedies and nosodes, he misread information demonstrating the safety of long-term homoeoprophylaxis (HP), and he appeared to be unaware of scientific evidence which is available supporting the prophylactic use of nosodes. These four areas are addressed in turn, and evidence from 1798 to 2012 is presented showing that appropriate homoeopathic immunisation using GE remedies and/or nosodes has the potential to prevent much suffering without any risk of possible short-term toxic damage or long-term energetic adverse effects.
\end{abstract}

Keywords: homoeopathy; high dilution; nosodes; immunisation

\section{Introduction}

Homoeopathic immunisation (homoeoprophylaxis - HP) is controversial even within the homoeopathic community. Teixeira, whilst writing to support the use of genus epidemicus (GE) remedies in the prevention of epidemic diseases, has attacked the prophylactic use of nosodes claiming that they "do not take the epistemological features of Hahnemann's homoeopathy into account nor exhibit scientific evidence". He has further suggested that advocates of this approach, such as Dr Dorothy Shepherd and this author, "transgress the bioethical principles of beneficence and non-maleficence"[1].

However Teixeira has failed to fully understand the principle of similars, he has used a double standard when comparing evidence using GE remedies and nosodes, he has misread information demonstrating the safety of long-term HP, and he appears to be unaware of scientific evidence which is available supporting the prophylactic use of nosodes.

\section{The principle of similars}


Teixeira correctly stated that when applied to homoeopathic treatment, the principle of similars indicates that, "substances causing symptoms on healthy individuals can be used to heal similar symptoms in sick individuals"[1, p.157].

However, when applied to homeopathic prevention, the principle of similars can be restated in two ways:

(1) A substance that can cure symptoms of an infectious disease is capable of preventing similar symptoms in previously unprotected people. Hahnemann's use of Belladonna to both cure and prevent scarlet fever is an example of this statement.

(2) A substance that can cause symptoms similar to the common symptoms of an infectious disease is capable of preventing similar symptoms in previously unprotected people. Hahnemann's proving of China officinalis is an example of this statement, as is the use of appropriately selected nosodes.

It is correct that if different outbreaks of the same disease produce dissimilar symptoms, then a single remedy will not provide effective prophylaxis in both outbreaks. However, if the common symptoms of different outbreaks are similar, then a remedy chosen because of its similarity to these common symptoms (whether a GE remedy or a nosode) will be effective in both. This statement holds true even though different people acquiring the disease may need different remedies for treatment. This is the very reason why Kent stated that "you will find that for prophylaxis there is required a less degree of similitude than is necessary for curing ... We must look to homeopathy for our protection as well as for our cure"[2].

Teixeira incorrectly interprets Hahnemann's attack on the use of isopathy in Aphorism 56 - "a method of curing a given disease by the same contagious principle that produces it" [1, p.161] - as an attack on the use of nosodes in disease prevention. Firstly, it is highly unlikely that the organism used to prepare a nosode of, say, pertussis would be identical with the strain of the organism against which it is being used as preventative. It certainly would not use material from the same patient as in true isopathy, where, for example, a patient's own blood or urine is potentised and prescribed to the patient as a remedy. Thus, we are not using "the same". Secondly, Hahnemann was referring to treatment of established diseases, not to the prevention of a disease. Thirdly, Hahnemann elsewhere stated that once a substance is potentised it is no longer identical - "even if the prepared itch substance should be given to the same patient from whom it was taken, it would not remain idem (the same), as it could only be useful to him in a potentized state, since crude itch substance which he has already in his body as an idem is without effect on him. But the dynamization or potentizing changes it and modifies it; ... Thus potentized and modified also, the itch substance (Psorin) when taken is no more an idem (same) with the crude original itch substance, but only a simillimum (thing most similar)"[3]. So Hahnemann expressed a range of views on this issue.

Teixeira incorrectly stated that nosodes could not be used homoeopathically, because they have not been subjected to pathogenic trials (provings). In fact, some small provings of a range of nosodes have been undertaken. However, just as the use of toxicological information pertaining to a substance can appropriately be incorporated into the materia medica of the substance alongside provings, so can knowledge of the common symptoms produced by an organism be used in the materia medica of that organism[4]. So, as noted above, it is possible to select nosodes for use in a HP program based totally on the principle of similars and, in fact, that is the only basis on which any substance used in a HP program should be selected.

\section{Evidence supporting the efficacy of GE remedies}


Teixeira presents a thorough outline of the use of homoeopathy in epidemic diseases. However, most of the evidence presented relates to the successful use of homoeopathy in treating resulting cases of disease, not in prevention. There are a few examples given relating to prevention using GE remedies, none of which formed part of randomised control trials (RCTs). However, when Teixeira attacked the use of HP, he complained that there was an absence of controlled clinical studies. This is a clear double standard, as is his criticism of HP using nosodes because there is no evidence that antibodies are produced, without applying the same test to GE results. In fact, homoeopathic immunisation using either approach does not rely on antibody stimulation, and thus testing is not expected to show changed antibody levels.

Teixeira describes some of the relatively few RCTs used to evaluate homoeopathic treatment, about which there is considerable disagreement between the homoeopathic and allopathic professions. In addition, the use of RCTs is increasingly seen within the allopathic literature to be problematical due to fundamental flaws in design, which means that the practical relevance of findings is frequently compromised [5,6,7].

Thus, just as the findings of well-constructed studies using GE remedies should be accepted, so should wellconstructed studies using nosodes. Examples of such studies will be presented below.

\section{Evidence of the safety of HP using nosodes}

Teixeira incorrectly states, "Golden reports rates of adverse effects higher than $10 \%$ in children subjected to this method - similar to those of conventional vaccination"[1. p.165]. In fact, the per-dose reaction rate was $1.5 \%[8]$, which is considerably less than that expected per dose from vaccination.

Further, the author conducted a separate study examining the long-term safety of four methods of immunisation - vaccination, HP, constitutional protection, and no method at all. The results using diagnoses made by general practitioners (GPs) are presented in Table 1, which clearly show that the use of appropriate long-term HP is significantly less damaging than vaccination and, as a fact, appears to be no less safe than the use of general or constitutional treatment as an immunisation option. They show, for example, that vaccinated children have 15 times greater odds of developing asthma than children using an appropriate HP program (based on nosodes)[9].

Table 1: Comparative long-term safety of HP using GP diagnoses

\begin{tabular}{|l|c|c|c|c|c|}
\hline & & \multicolumn{5}{|c|}{ Method } \\
\hline Condition & Measurement & HP only & Vaccination only & General only & Nothing \\
\hline Asthma & Odds ratio & $\mathbf{0 . 1 2 4}$ & $\mathbf{1 . 8 9}$ & 0.49 & $\mathbf{0 . 6 9}$ \\
\hline & Chi test P & $\mathbf{0 . 0 0 0 6}$ & $\mathbf{0 . 0 0 0 7}$ & 0.13 & $\mathbf{6 . 5 E - 4 0}$ \\
\hline \multicolumn{7}{|c|}{} & $\mathbf{1 . 7 6}$ & $\mathbf{0 . 2 2 5}$ & $\mathbf{0 . 6 6 5}$ \\
\hline Eczema & Odds ratio & $\mathbf{0 . 2 3 9}$ & $\mathbf{0 . 0 0 6}$ & $\mathbf{0 . 0 2 5}$ & $\mathbf{6 . 5 E - 4 0}$ \\
\hline & Chi test P & $\mathbf{0 . 0 0 9 7}$ & & 0.599 & $\mathbf{0 . 4 0 1}$ \\
\hline & Odds ratio & 0.703 & $\mathbf{1 . 5 1 7}$ & 0.282 & $\mathbf{9 . 4 E - 4 1}$ \\
\hline Ear/ & Chi test P & 0.364 & $\mathbf{0 . 0 4}$ & & $\mathbf{0 . 6 0 8}$ \\
\hline Hearing & & & 1.518 & 0.446 & \\
\hline
\end{tabular}




\begin{tabular}{|c|c|c|c|c|c|}
\hline \multicolumn{7}{|c|}{ Chi test P } & $\mathbf{0 . 0 3 8}$ & 0.061 & 0.171 & $\mathbf{5 . 8 E}-40$ \\
\hline Behaviour & Odds ratio & $\mathbf{0 . 5 4 1}$ & 0.784 & $\mathbf{1 . 6 7 5}$ & $\mathbf{0 . 7 8 4}$ \\
\hline & Chi test P & $\mathbf{0 . 0 5 5}$ & 0.613 & $\mathbf{0 . 0 4 9}$ & $\mathbf{1 . 2 E}-\mathbf{4 0}$ \\
\hline
\end{tabular}

\section{Scientific evidence of the effectiveness of HP using nosodes}

There is a growing body of rigorous scientific evidence supporting the effectiveness of homoeopathic immunisation whether using GE remedies or nosodes. There are very few if any RCTs of value, however, as stated above, this in no way limits the value of the findings of well-constructed studies. These studies cover both short-term and long-term uses.

Short-term: one of the best reports (in English) of the use of nosodes for short-term protection was during an outbreak of meningococcal meningitis type B in Brazil in 1998. The doctors conducting the intervention in 65,826 children followed this group plus another group of 23,539 unimmunised children for 12 months. They reported an effectiveness of intervention of $95 \%$ after 6 months and $91 \%$ after 12 months[10].

Long-term: the research conducted by the author from 1986 to 2004 using long-term HP, mainly nosodes based and one GE remedy, yielded the following results surveying 2,342 child-years: effectiveness $=90.4 \%$ confidence interval $(95 \%-\mathrm{CI})=(87.6 \%-93.2 \%)(\mathrm{p}=0.05)[11]$.

The study was not controlled. However, it is possible to use a de facto control via national attack rates for the three diseases for which there were failures. Table 2 shows these figures.

Table 2: Comparison of national and HP attack rates

\begin{tabular}{|l|l|l|l|}
\hline Disease & Attack rate, unimmunised \% & Attack rate, HP \% & Efficacy of HP \% \\
\hline Whooping Cough & 85.0 & 11.7 & 86.2 \\
\hline Measles & 90.0 & 9.0 & 90.0 \\
\hline Mumps & 70.0 & 5.9 & 91.6 \\
\hline
\end{tabular}

It is appropriate to acknowledge the significant contribution made to HP evidence by scientists at Finlay Institute in Havana, Cuba. They performed interventions in 2007 and 2008 in over 2.2 million people against increasing levels of leptospirosis triggered by severe hurricane damage[12]. The interventions were highly successful, and led to the homoeopathic immunisation (based on nosodes) of the entire country population over 12 months of age against swine flu in 2009/10, to wit, about 9.8 million people. HP is also being used against pneumococcal disease, hepatitis $\mathrm{A}$ and dengue fever. The Cubans generally use a combination of nosodes and GE remedies. Whilst this is not the approach used by the author, the Cuban approach does work almost certainly, because every remedy in the mixture has a degree of similarity to the common symptoms of the infectious disease it aims to prevent. 
Table 3 provides a snapshot of the use of HP, both GE remedies and nosodes, from Hahnemann's time till this day. Quantified measures of effectiveness were shown to be comparably effective to results using vaccines in real-life situations.

Table 3: Snapshot of the historical use of HP

\begin{tabular}{|c|c|c|c|c|c|}
\hline Year & Author(s) & Disease & Type & Numbers & Effectiveness \\
\hline 1798 & Hahnemann[13] & Scarlet fever & GE & & \\
\hline 1801 & Dudgeon[14] & Scarlet fever & GE & 1,646 & $92.9 \%$ \\
\hline 1831 & Hahnemann[15] & Cholera & GE & & \\
\hline 1831 & Hufeland[16] & Scarlet fever & GE & & \\
\hline 1849 & von Boenninghausen[17] & Cholera & GE & & \\
\hline 1884 & Burnett[18] & Smallpox & Nosode & & \\
\hline 1900 & Kent[19] & Various & GE & & \\
\hline 1907 & Eaton[20] & Smallpox & Nosode & 2,806 & $97.5 \%$ \\
\hline 1920 & Close[21] & Various & GE & & \\
\hline 1932 & Chavanon[22] & Diphtheria & Nosode & & \\
\hline 1941 & Patterson and Boyd[23] & Diphtheria & Nosode & 33 & \\
\hline 1950 & Taylor Smith[24] & Polio & GE & 82 & No cases reported \\
\hline 1956 & Heisfelder[25] & Polio & GE & 6,000 & No cases reported \\
\hline 1963 & Gutman[26] & Influenza & Nosode & 385 & $86.0 \%$ \\
\hline 1967 & Shepherd[27] & Various & Nosode/GE & & \\
\hline 1968 & Krishnamurty[28] & Influenza & Nosode & & \\
\hline 1972 & Sankaran P[29] & Various & Nosode/GE & & \\
\hline 1974 & Castro \& Noguiera[30] & Meningitis & Nosode & $18,640 / 6,340$ & $86.1 \%$ \\
\hline 1976 & Blackie[31] & Influenza & Nosode & & \\
\hline 1976 & Mathur[32] & Various & Nosode/GE & & \\
\hline 1982 & Speight[33] & Various & Nosode/GE & & \\
\hline 1989 & Lockie[34] & Various & Nosode/GE & & \\
\hline 1991 & Eizayaga[35] & Various & Nosode & & \\
\hline 1991 & Sethi[36] & $\begin{array}{l}\text { Diphtheria; } \\
\text { Measles; Polio; } \\
\text { Pertussis }\end{array}$ & Nosode/GE & & \\
\hline 1993 & Lessell[37] & Various & Nosode/GE & & \\
\hline
\end{tabular}




\begin{tabular}{|c|c|c|c|c|c|}
\hline 1996 & CCRH[38] & Dengue fever & Nosode & 23,250 & $99.8 \%$ \\
\hline 1998 & Mroninski[10] & $\begin{array}{l}\text { Meningitis type } \\
\text { B }\end{array}$ & Nosode & 65,826 / 23,539 & $92.4 \%-91.0 \%$ \\
\hline 1999 & Srinivasulu[39] & $\begin{array}{l}\text { Japanese } \\
\text { encephalitis }\end{array}$ & GE & 20million & $\begin{array}{l}\text { Cases reduced to } 0 \\
\text { after } 3 \text { years }\end{array}$ \\
\hline 2001 & Marino[40] & Dengue fever & GE & & \\
\hline 2003 & Partington[41] & Malaria & Nosode & 33 & \\
\hline 2004 & Golden[11] & $\begin{array}{l}\text { Pertussis; } \\
\text { Measles; Mumps }\end{array}$ & Nosode & $\begin{array}{l}2,342 \text { child- } \\
\text { years }\end{array}$ & $\begin{array}{l}\text { Pertussis }=86.2 \% ; \\
\text { Mumps }=91.6 \% ; \\
\text { Measles }=90.0 \%\end{array}$ \\
\hline 2006 & Minah \& Margai[42] & Malaria & Nosode & 731 & \\
\hline 2007 & Nunes[43] & Dengue fever & GE & 156,129 & $\begin{array}{l}\text { Significant fall in } \\
\text { cases }\end{array}$ \\
\hline 2007 & Institute, & Leptospirosis & $\begin{array}{l}\text { Nosode } \quad+ \\
\text { GE }\end{array}$ & 2.2 million+ & $\begin{array}{l}\text { Significantly } \\
\text { fewer cases }\end{array}$ \\
\hline 2008 & $\begin{array}{ll}\text { Finlay } & \text { Institute, } \\
\text { Cuba[12] } & \end{array}$ & Leptospirosis & $\begin{array}{l}\text { Nosode }+ \\
\text { GE }\end{array}$ & 2.2 million+ & $\begin{array}{l}\text { Significantly } \\
\text { fewer cases }\end{array}$ \\
\hline
\end{tabular}

These few examples point to the range of evidence available from well-constructed and rigorous HP interventions using both GE remedies and nosodes. There are more, and fortunately there is on-going research in different countries to expand the evidentiary base of HP.

\section{Conclusions}

Teixeira's contribution was thorough and contains valuable information. It is disappointing that the misunderstandings and errors noted above regarding the appropriate use of nosodes to prevent targeted infectious diseases led Teixeira to attack the many thousands of homoeopathic practitioners worldwide who use appropriate HP programs based on nosodes as transgressing "the bioethical principles of beneficence and non-maleficence".

Nothing could be further from the truth. In fact, evidence shows that appropriate homoeopathic immunisation using GE remedies and/or nosodes has the potential to prevent much suffering without any risk of possible short-term toxic damage or long-term energetic adverse effects.

\section{References}

[1] MZ Teixeira. Homeopathy: a preventive approach to medicine? Int J High Dilution Res [online]. 2009 $\begin{array}{llllll}\text { [cited } 2013 & \text { October } & \text { 8(29): } & \text { 155-172. Available from: }\end{array}$ http://www.feg.unesp.br/ ojs/index.php/ijhdr/article/view/360/407

[2] Kent JT. Lecture 29, Lectures on Homoeopathic Philosophy. 1900. B.Jain Publishing. New Delhi. Page 229.

[3] Hahnemann S, The Chronic Diseases 1838. B.Jain Publishing. New Delhi. Page 152. 
[4] Vermeulen F. Monera. Emryss Publishers, Haarlem, The Netherlands. 2005.

[5] Walach $\mathrm{H}$. The efficacy paradox in randomized controlled trials of CAM and elsewhere: beware of the placebo trap. J Altern Complement Med 2001; 7: 213-18.

[6] Ioannidis JPA. Why most published research findings are false. PLoS Med 2005; 2: e124.

[7] Golden I. Beyond Randomized Controlled Trials: Evidence in Complementary Medicine. Journal of Evidence-Based Complementary \& Alternative Medicine Volume 17 Issue 1 January 2012. 2012. DOI $10.1177 / 2156587211429351$

[8] Golden I. Vaccination \& Homoeoprophylaxis? A review of risks and alternatives. 7th edition. Gisborne: Isaac Golden Publications, 2010. Page 150.

[9] Golden I. Homoeoprophylaxis: A Fifteen Year Clinical Study. Isaac Golden Publications, Gisborne, Australia. 2005. Page 40.

[10] Mroninski C, Adriano E, Mattos G (2001) Meningococcinum: Its protective effect against meningococcal disease. Homeopathic Links Winter Vol 14(4); pp. 230-4.

[11] Golden I. The Complete Practitioner's Manual of Homoeoprophylaxis, Isaac Golden Publications, Gisborne, Australia. 2012. Page 66.

[12] Bracho G, Varela E, Fernández R, et al. Large-scale application of highly-diluted bacteria for Leptospirosis epidemic control. Homeopathy. 2010; 99: 156-

[13] Hahnemann S. The Cure and Prevention of Scarlet Fever, Lesser Writings. B.Jain Publishing. New Delhi. 1801. P.369ff.

[14] Dudgeon R. E. 1853. Lectures on the Theory and Practice of Homeopathy. p.541,2. Republished by B. Jain Publishers, 2002, New Dehli.

[15] Hahnemann S. Cause and Prevention of the Asiatic Cholera. 1831. Lesser Writings. B.Jain Publishing. New Delhi. 1801. P.369ff.

[16] Hufeland CW, Prophylactic Power of Belladonna in Scarlet Fever. Hufeland's Journal, 1826.

[17] von Boenninghausen CMF, Brief Instructions for Non-Physicians Concerning the Prophylaxis and Treatment of Asiatic Cholera, Lesser Writings. B.Jain Publishers, New Delhi, 1986 (reprint). p. 303.

[18] Burnett JC, Vaccinosis and its Cure by Thuja; with Remarks on Homœoprophylaxis. W H L, 1992 (reprint), pp. 114, 115.

[19] Kent JT, Lectures on Homoeopathic Philosophy. B. Jain Publishers, New Delhi, 5th Edition, 1954, p. 229.

[20] Eaton CW, Variolinum, Transactions of the American Institute of Homoeopathy, 1907. www.whale.to/v/eaton.html .

[21] Close S, The Genius of Homoeopathy. B. Jain Publishers, New Delhi, 1991, p. 20. 
[22] Chavanon, P. La Dipterie, $4^{\text {th }}$ edition. St. Denis, Niort: Imprimerie 1932.

[23] Patterson, J and Boyd WE. Potency Action: A Preliminary Study of the Alteration of the Schick Test by a Homeopathic Potency. British Homeopathic Journal. 1941; 31: 301-309.

[24] Taylor-Smith A. Poliomyelitis and prophylaxis. Br Homeopath J. 1950 Apr;40(2):65-77. PMID: 15420319.

[25] Eisfelder, HW, Poliomyelitis Immunization: A Final Report. Journal of the American Institute of Homeopathy. V. 54, Nov-Dec 1961, pp. 166-167.

[26] Gutman W. Homeopathic oral vaccine against influenza. Homeopathy. 1963. 13(12); pp. 185, 187.

[27] Dr Dorothy Shepherd, Homoeopathy in Epidemic Diseases. Health Science Press, 1981 reprint, p. 15.

[28] Krishnamurty, Report on the use of Influenzinum during the outbreak of epidemic in India in 1968. Hahnemannian Gleanings. 1970;37:225-6.

[29] Sankaran P, Prophylactics in Homoeopathy. The Homoeopathic Medical Publishers, 1961.

[30] Castro D \& Nogueira GG, Use of the Nosode Meningococcinum as a preventative Against Meningitis. J.A.I.H. 68: 1975; pp. 211-219

[31] Blackie M, The Challenge of Homoeopathy. Unwin, 1981, p. 184.

[32] Mathur DK, Principles of Prescribing. B.Jain Publishers, New Delhi, 1987 (reprint), pp. 50, 53.

[33] Speight LJ, Homoeopathy and Immunisation. Health Science Press. 1982. p. 3.

[34] Lockie A, The Family Guide to Homoeopathy. Guild Publishing. 1989. p. 17.

[35] Eizayaga FX, Treatise on Homoeopathic Medicine. E Marecel, Buenos Aires. 1991. pp. 282-286.

[36] Sethi B, Homoeo Prophylactic Remedies. B.Jain Publishers, New Delhi, 1991. pp. 22, 47, 56, 78.

[37] Lessell CB, The World Traveller's Manual of Homoeopathy. C W Daniel Co Ltd,1993. Page 14.

[38] Central Council of Research in Homoeopathy. CCRH News 1996-1997.

[39] Srinivasulu G. Poster presentation. 60 th Homeopathic World Medical Congress. Berlin. 4-7/5/2005.

[40] Marino R. Homeopathy and Collective Health: The Case of Dengue Epidemics. Int J High Dilution Res 2008; 7(25):179-185. http://www.feg.unesp.br/ ojs/index.php/ijhdr/article/viewFile/312/373

[41] Partington, T. Silent and Deadly: Prophylaxis and Treatment of Malaria. Homeopathy in Practice, 2006, pp.14-19.

[42] Minah J and Margai FM. The Use of Malaria Nosodes to Reduce the Prevalence of Malaria in Depressed Communities. Minah JB: Anfrage nach Unterstützung einer Forschungsarbeit an das Sekretariat des DZVhÄ. 20. Oktober. 2006. 
[43] Nunes LA de S. Contribution of homeopathy to the control of an outbreak of dengue in Macaé, Rio de $\begin{array}{llllll}\text { Janeiro. Int } & \mathrm{J} & \text { High } & \text { Dilution } & \text { Res. } & \text { 2008; }\end{array}$ http://www.feg.unesp.br/ ojs/index.php/ijhdr/article/viewFile/315/374

[44] Lyrio C et al. The use of homeopathy to prevent symptoms of human flu and acute respiratory infections: a double blind, randomized, placebo-controlled clinical trial with 600 children from Brazilian Public Health $\begin{array}{lllll}\text { Service. Int J High Dilution } \quad \text { Res } \quad 2011 ; & \text { 10(36):174-176 }\end{array}$ http://www.feg.unesp.br/ ojs/index.php/ijhdr/article/view/499/513

\title{
Base filosófica e evidências da imunização homeopática: resposta a Teixeira
}

\begin{abstract}
RESUMO
A imunização homeopática foi utilizada pela primeira vez em 1798, no entanto, continua sendo uma prática controvertida entre os homeopatas. Teixeira defende o uso de medicamentos do gênio epidémico (GE), mas condena veementemente o uso de nosódios na prevenção de doenças. Contudo, Teixeira não tem compreendido completamente o princípio de similitude, utilizou um padrão duplo na sua comparação das evidências resultantes do uso de medicamentos GE e nosódios, fez uma leitura equívoca das informações que demonstram a segurança da homeoprofilaxia no longo prazo e parece não ter ciência de evidências científicas disponíveis embasando o uso de nosódios. Esses quatro tópicos são abordados aqui, além da apresentação de evidências coletadas de 1798 a 2012 que demonstram que una imunização homeopática adequada baseada no uso de medicamentos do GE e/ou nosódios tem potencial para prevenir muito sofrimento sem risco de lesões tóxicas no curto prazo nem de efeitos adversos energéticos no longo prazo.
\end{abstract}

Palavras-chave: homeopatia; alta diluição; nosódios; imunização

\section{Base filosófica y evidencias a favor de la inmunización homeopática: respuesta a Teixeira}

\section{RESUMEN}

La inmunización homeopática fue utilizada por vez primera en 1798, sin embargo, continua siendo controvertida entre homeópatas. Teixeira defiende el uso de medicamentos del genio epidémico (GE), pero condena vehementemente el uso de nosodes en la prevención de enfermedades. No obstante, aparentemente Teixeira no ha comprendido totalmente el principio de semejanza, utilizó un duplo estándar en la comparación de las evidencias resultantes del uso de medicamentos GE y nosodes, realizó una lectura equivocada de informaciones que demuestran la seguridad de la homeoprofilaxia a largo plazo y aparentemente no está a la par de evidencias científicas disponibles apoyando el uso de nosodes. Estos cuatro tópicos son aquí abordados, junto con la exposición de evidencias acumuladas entre 1798 y 2012, que demuestran que una adecuada inmunización homeopática basada en el uso de medicamentos GE y/o nosodes posee potencial para evitar mucho sufrimiento sin riesgos de lesiones tóxicas a corto plazo ni de efectos adversos energéticos a largo plazo.

Palabras clave: homeopatía; alta dilución; nosodes; inmunización 


\section{(c)) BY-Nc-ND Licensed to GIRI}

Support: authors declare that this study received no funding

Conflict of interest: authors declare there is no conflict of interest

Received: October 24th 2013; Revised: February 26 th 2014 ; Published: March 25 th 2014

Correspondence author: Isaac Golden, admin@homstudy.net, http://www.homstudy.net

How to cite this article: Golden I. The Philosophical and Evidentiary Basis of Homoeopathic Immunisation: a Response to

Teixeira. Int $J$ High Dilution Res [online]. 2014 [cited YYYY Month dd]; 13(46): 45-53. Available from: http://www.feg.unesp.br/ ojs/index.php/ijhdr/article/view/687/692 